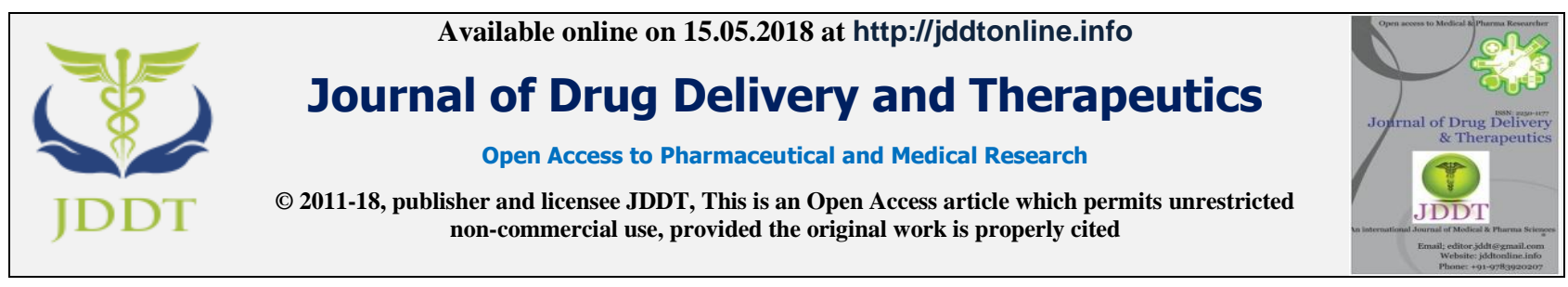

Open $\odot$ Access

Research Article

\title{
IMMUNOMODULATORY EFFECT OF PARKIA JAVANICA EXTRACT ON INTRACELLULAR EXPRESSION OF IL-6, IL-8, IL-12 AND TNF- $\alpha$
}

\author{
Saha $\mathbf{S}^{1}$, Dinda $\mathbf{M}^{2}$, Karmakar $\mathbf{P}^{2}$, Sil $\mathbf{S} \mathbf{K}^{\mathbf{1}^{*}}$ \\ ${ }^{1}$ Molecular Genetics \& Cell Physiology Lab, Department of Human Physiology, Tripura University, Suryamaninagar, Tripura-799022, India \\ ${ }^{2}$ Department of Life Science \& Biotechnology, Jadavpur University, 188, Raja S. C. Mallick Road, Kolkata, West Bengal-700032, India
}

\section{ABSTRACT}

The crude methanol extract of Parkia javanica (crude MEPJ) was screened for immunomodulatory activity on macrophage cells, RAW 264.7, by cell proliferation, migration and qRT PCR based interleukin expression assays. The maximum proliferation and migration of macrophage cells were observed at the dose of $20 \mu \mathrm{g} / \mathrm{ml}$. The expression of proinflammatory cytokines, IL- 6 , IL-8, IL12 and TNF- $\alpha$ were increased after treatment with crude MEPJ. This study clearly suggests the immune stimulant property of Parkia javanica on macrophage cells.

Keywords: Parkia javanica, macrophage cells, interleukins, immunomodulatory.

Article Info: Received 10 March, 2018; Review Completed 25 April 2018; Accepted 26 April 2018; Available online 15 May 2018

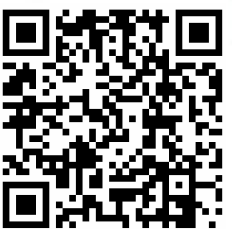

Cite this article as:

Saha S, Dinda M, Karmakar P, Sil SK, Immunomodulatory effect of Parkia javanica extract on intracellular expression of IL-6, IL-8, IL-12 AND TNF- $\alpha$ Journal of Drug Delivery and Therapeutics. 2018; 8(3):58-63

DOI: http://dx.doi.org/10.22270/jddt.v8i3.1768

*Address for Correspondence:

Sil S.K., Molecular Genetics and Cell Physiology Lab, Department of Human Physiology, Tripura University, Suryamaninagar, Tripura799022, India

\section{INTRODUCTION}

The immune system is a remarkably developed defence system that protects vertebrates from foreign bodies. The immune system produces many cells and molecules that distinguish and eliminate foreign and unwanted agents ${ }^{1}$. The modulation of the immune system refers to any alteration in the immune response, including stimulation, expression, amplification, or inhibition of any portion or stage of the immune response. Therefore, immunomodulators are substances used for their effects on the immune system. Immunomodulators are grouped into two types based on their effects: immunostimulators and immunosuppressors. These immunomodulators mount an immune response or defend against pathogens or tumors ${ }^{2}$. Immunomodulators are substances that modify the response of the immune system to a threat. Immunomodulators modulate and potentiate the immune system, keeping it highly prepared for any threat ${ }^{3}$. Currently, worldwide, there is an increase in diseases especially infectious diseases that requires efficient body defense mechanisms to control them through the process of immunomodulation ${ }^{4}$. Plant-derived compounds, bacterial products, synthetic drugs and marine compounds have been used as immunomodulation agents ${ }^{5}$. However, plant-derived compounds also have an important role as compared to many of the other immunomodulators because of their broad spectrum of therapeutic properties and low toxicity ${ }^{6}$. Among various immune system-related cells, macrophages are versatile cells that exist in almost all tissues and play important roles in immune responses ${ }^{7,8}$. In particular, macrophages are recruited in infection sites where they are activated to perform many functions through increasing phagocytosis. This process is the first line of defence against microbial and parasitic infections and in removing senescent and dead cells, immune mediator secretion, and antigen presentation ${ }^{9,10}$. In the innate immune system activated macrophages also prevent the invasion of pathogens by secreting inflammatory mediators, including nitric oxide (NO), prostaglandin E2 (PGE2), and cytokines, such as TNF- $\alpha$ and interleukins (ILs) ${ }^{11-15}$. Modulation of macrophage activity by drugs/exogenous substances can be used to counter many of these pathologic states ${ }^{5}$. Parkia javanica a plant 
of leguminece family, has long ethnomedicinal history among different population of north eastern region of India $^{16,17,18}$. This work has been undertaken to explore the effect of Parkia javanica extract on macrophage cells in in vitro system.

\section{MATERIALS AND METHODS}

\section{Plant collection \& Authentication}

Fresh stem barks of $P$. javanica were collected from Suryamaninagar, Tripura, India. The plant was initially identified by Dr. B. K. Dutta, Taxonomist, Department of Botany, Tripura University and finally authenticated by Dr. H. J. Chowdhery, Joint Director, Central National Herbarium, Botanical Survey of India, Shibpur, Howrah, West Bengal and respective voucher specimen No. $\neq \mathrm{BD}-01 / 06$ has been deposited in the Herbarium.

\section{Preparation Plant Extract}

After washing with water fresh stem barks of Parkia javanica were allowed to dry in shade. Then $500 \mathrm{gm}$ of powdered bark was soaked in $2000 \mathrm{ml}$ of methanol to prepare the crude methanol extract of Parkia javanica (crude MEPJ) and then kept in a shaker for 48 hours. After that the solution was filtered through Whatman filter paper no. 1 for 3 times. Then the solution was dried in rotary evaporator at $70^{\circ} \mathrm{C}$. Finally these solutions were freeze- dried and stored at $-20^{\circ} \mathrm{C}^{19}$.

\section{Immunomodulatory effect in vitro}

\section{Cell lines}

Mouse macrophage cells (Raw 264.7) were purchased from National Centre for Cell Science, Pune, India.

\section{Cell culture}

Macrophage cell lines, Raw 264.7, were maintained in DMEM and supplemented with $10 \%$ FBS, $100 \mathrm{IU} / \mathrm{mL}$ penicillin and $100 \mu \mathrm{g} / \mathrm{mL}$ streptomycin, at $37{ }^{\circ} \mathrm{C}$ in a humidified atmosphere containing $5 \% \mathrm{CO} 2$ (ESCO, Singapore).

\section{Cell Proliferation assay}

Cells were cultured in 96 well plate tube with or without different concentration of crude MEPJ for $24 \mathrm{~h}$ time duration. The cells viability was assessed using MTT assay method $^{20}$. 3-[4,5-dimethylthiazol-2-yl]-2,5diphenyltetrazolium bromide (MTT) was dissolved in phosphate-buffered saline at a concentration of 5 $\mathrm{mg} / \mathrm{mL}$. MTT was added to each well, and plates were incubated at $37^{\circ} \mathrm{C}$ for $3 \mathrm{~h}$. The medium was replaced with $100 \mu \mathrm{L}$ DMSO, and the absorbance for each well will be measured at $570 \mathrm{~nm}$ on a microplate reader. Total viable cell count was taken at different time periods of $24 \mathrm{~h}, 48 \mathrm{~h}$ and $72 \mathrm{~h}$.

\section{Cell migration assay}

Mouse macrophage (Raw 264.7) cells were treated with crude MEPJ and an artificial wound was created on culture plates by scratching the plates through microtips. Microscopic images were taken immediately after wounding and during an incubation period of up to 72 hours. Finally the activity of the crude MEPJ was compared with the control and measured by calculating the percentage of closed area ${ }^{21,22}$.

\section{In vitro stimulation of intracellular cytokines production}

Total RNA was isolated using Qiagen RNeasy mini kit, according to the manufacturer's protocol. One microgram of total RNA was reverse transcribed using iScript reverse transcription supermix for RT-qPCR (Applied Biosystem) and the resulting cDNA was amplified by PCR using specific primers for the studied genes. The thermal cycling condition was set as denaturation for $30 \mathrm{~s}$ at $95^{\circ} \mathrm{C}$, annealing for $30 \mathrm{~s}$ at appropriate $\mathrm{Tm}$ and elongation for $45 \mathrm{~s}$ at $72{ }^{\circ} \mathrm{C}$ with a final extension for $7 \mathrm{~min}$ at $72^{\circ} \mathrm{C}$ and it was ensured that amplicons were in the linear phase of amplification. PCR amplification cycles were performed using a Applied Biosystems, Waltham, MA, USA; 7500 Fast Real-Time PCR). Real-time PCR was done to quantify the amount of product using Syber green PCR master mix kit (Applied Biosystems, CA, USA). After each cycle a melting curve analysis was performed to check that no primer dimers or nonspecific products were formed. Fold induction of a gene was calculated using an equation: Fold induction $=2^{\Delta \Delta \mathrm{Ct}}$, where $\mathrm{Ct}$ stands for threshold cycle number for a gene ${ }^{23}$. The sequences of the primers ${ }^{24}$ are given in Table 1 .

Table 1: Oligonucleotides used for qPCR

\begin{tabular}{|l|l|l|c|}
\hline Gene & Forward Primer $\left(\mathbf{5}^{\prime} \mathbf{-} \mathbf{3}^{\prime}\right)$ & Reverse Primer $\left(\mathbf{3}^{\prime} \mathbf{-} \mathbf{5}^{\prime}\right)$ & Tm $\left({ }^{\circ} \mathbf{C}\right)$ \\
\hline \multicolumn{5}{|l|}{ Mouse Primers } \\
\hline IL-6 & GTTCTCTGGGAAATCGTGGA & GTACTCCAGGTAGCTATGG & 55 \\
\hline IL-8 & TGGCAGCCTTCCTGATTT & AGGTTTGGAGTATGTCTTTATGC & 54 \\
\hline IL-12 p40 & CAGAAGCTAACCATCTCCTGGTTTG & CCGGAGTAATTTGGTGCTCCACAC & 60 \\
\hline TNF $\alpha$ & AAGCCTGTAGCCCATGTTGTA & TCAGCTCCACGCCATTG & 50 \\
\hline$\beta$-actin & GTGGGCCGCTCTAGCCACCAA & TCTTTGATGTCACGCACGATTTC & 60 \\
\hline
\end{tabular}




\section{Statistical analysis}

All data were represented as mean \pm SEM. Differences among groups were evaluated using one-way ANOVA to determine statistical significance. $\mathrm{P}<0.05$ was accepted as statistically significant. $\mathrm{P}<0.05, \mathrm{P}<0.01$ are represented by $*, * *$ and $* * *$, respectively.

\section{RESULTS}

\section{Parkia javanica stimulates Macrophage proliferation}

MTT assay was used to examine the effect of Crude MEPJ on mouse macrophage cell line (Raw 264.7) proliferation. The cells were treated with different concentrations of crude MEPJ, and the cell viability was determined by MTT assay at $24 \mathrm{~h}, 48 \mathrm{~h}$ and $72 \mathrm{~h}$, respectively. As seen in Fig.1, after 24-h treatment, the proliferation of Raw 264.7 increased up to $140 \%$ in presence of crude MEPJ, compared to untreated control. Enhanced proliferation in macrophage cell line, after 48 $\mathrm{h}$ of crude MEPJ treatment was observed which increased slightly (Fig.1.). Thus crude MEPJ extract might have a significant role in the proliferation of macrophage cells.

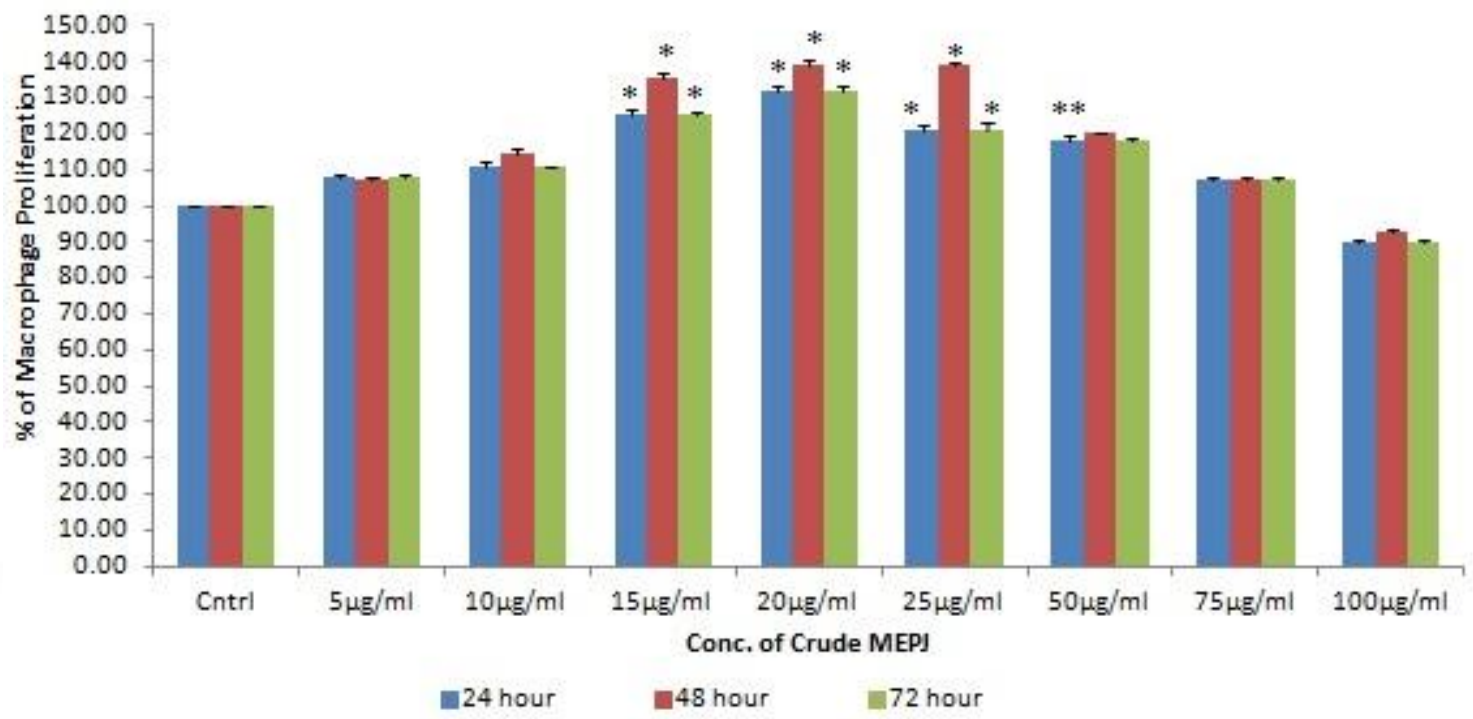

Figure 1: Histogram of \% of cell proliferation in presence of crude MEPJ on macrophage cell line (Raw 264.7). Results were expressed as mean $\pm \mathrm{SD}, \mathrm{n}=3$ and the statistical significance was calculated using one way ANOVA followed by Bonferroni test.* $(\mathrm{P}<0.05)$ and $* *(\mathrm{P}<0.01)$ in comparison to control (without extract).

\section{Parkia javanica increases Macrophage Migration}

As the proliferation of macrophage plays an important role in wound healing activity, we next explored the effect of crude MEPJ on the migration of Raw 264.7 cells in an in vitro wound healing model. In this model scrape wounds were generated in nearly confluent monolayer of cells, and the migration of the edge of the wound was monitored with a phase contrast microscope. Cells with or without crude MEPJ treatment were allowed to migrate into the void area for $0-72 \mathrm{~h}$. The macrophage cells started to migrate into the void area at $24 \mathrm{~h}$ after crude MEPJ treatment and wound area clouses up to $80 \%$ compared to respective wound area, and the void area of the cells was almost closed at $72 \mathrm{~h}$ and $48 \mathrm{~h}$, respectively. In contrast, the migration of untreated cells was slower at the corresponding time points. The gap width at each time point after treatment with crude MEPJ was measured and plotted in Fig 2.
A
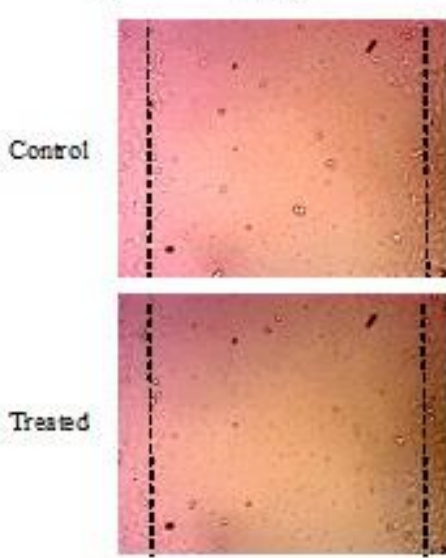

24 Hour
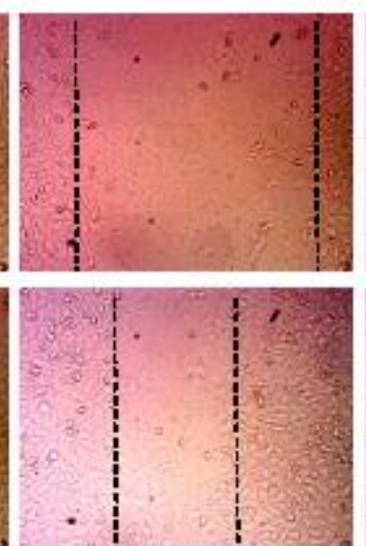

48 Howr
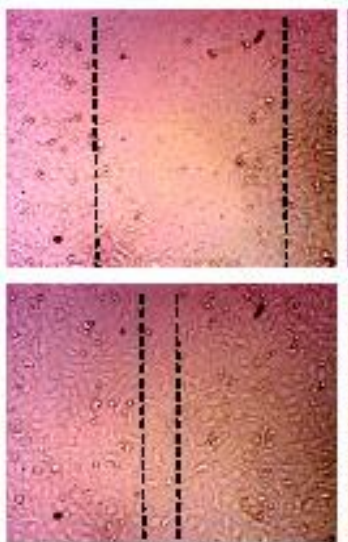

72 Hour

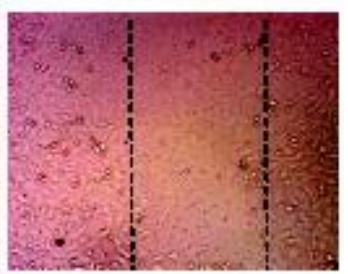

CONFLUENT

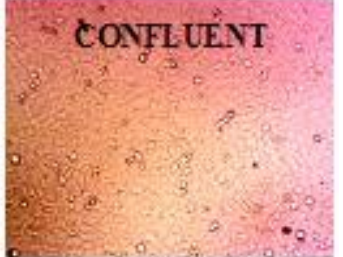




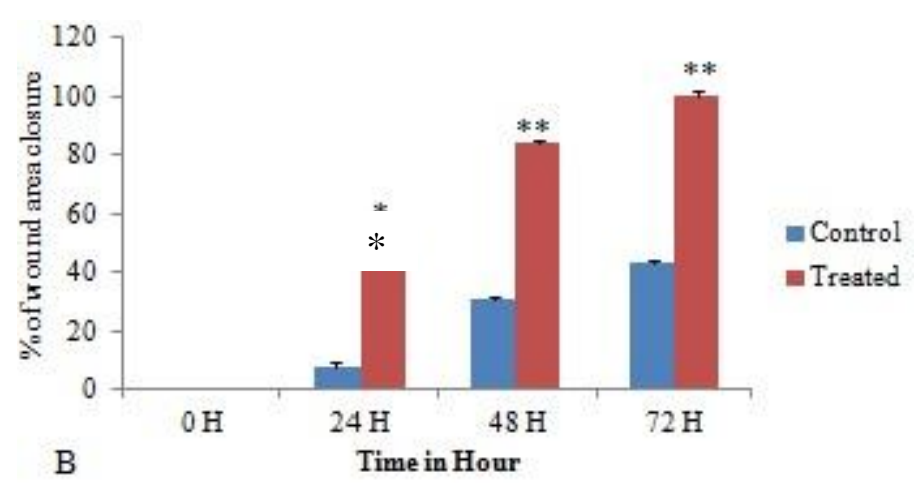

Figure 2: PJ (Parkia javanica) induced migration of macrophage cells in an in vitro wound model. (A) The wound is generated in monolayer cells and photographed with a phase contrast microscope (10X) immediately after wounding $(0$ h) and 24, 48 and $72 \mathrm{~h}$ later. (B) Gap of the wound areas were measured using ImageJ Software, and \% of wound closure with time is calculated. Results were expressed as mean $\pm \mathrm{SD}, \mathrm{n}=3$. * $(\mathrm{P}<0.05), * *(\mathrm{P}<0.01)$ in comparison to control (without extract) and the statistical significance was calculated using one way ANOVA followed by Bonferroni test. h, hour.

\section{Expression of IL-6, IL-8, IL-12 and TNF- $\alpha$.}

As various immune related cytokines, are produced by activated macrophages which are essential for the host survival of infection, modulation and orchestration of innate immunity, so next we explored the effect of crude MEPJ on such cytokines. In the present study induced expression of IL-6, IL-8, IL-12 $\mathrm{p}^{40}, \mathrm{TNF}-\alpha$, in treated macrophage cells compared to untreated cells was observed (Fig 3). The experiment revealed that, crude MEPJ treated cells showed increased ILs expression compared to untreated cells. The expressions of IL-6, IL-8 were increased up to 3 to 3.5 fold change. The expression of IL-12 $\mathrm{p}^{40}$ was also increased after treatment with crude MEPJ extract. In macrophage cell line the expression of TNF- $\alpha$ significantly increased after treatment.

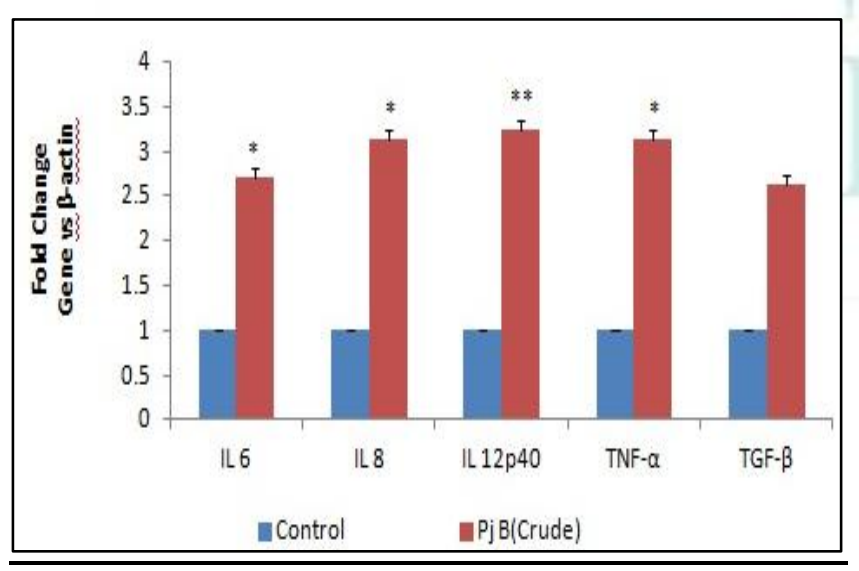

Figure 3: mRNA levels of IL6, IL8, IL12p40 and TNF- $\alpha$ were quantified by qPCR from the total RNA isolated from Raw 264.7 cells treated with crude MEPJ $(20 \mu \mathrm{g} / \mathrm{ml})$. Results were expressed as mean $\pm \mathrm{SD}, \mathrm{n}=3$. * $(\mathrm{P}<0.05), * *(\mathrm{P}<0.01)$ in comparison to control (without extract) and the statistical significance was calculated using one way ANOVA followed by Bonferroni test.

\section{DISCUSSION}

The modulation of immune response to combat diseases has long been a topic of interest. Many recent studies made progress in the research on ethnomedicinal plants as immunomodulatory agents. It is an interesting area for inflammation, autoimmunity and anticancer therapy ${ }^{25,26}$. Numerous plants are used in traditional medicinal system showed to stimulate or inhibit the immune responses ${ }^{27}$. Medicinal plants and their products are most useful in health and disease treatment through the involvement of various biological activities like antioxidant and anti-ulcerogenic activities ${ }^{28}$. Moreover several medicinal plants possess immunomodulatory activities as they impart anti-inflammatory, antimicrobial, and anti-tumor effects under varying experimental conditions.

Macrophages are the first line of defence in the innate immunity against microbial infection, and phagocytes engulf and kill microorganisms and present antigens that elicit adaptive immune responses ${ }^{29}$. Macrophages serve an important function in tissue remodelling through development, wound healing, and tissue homeostasis. Macrophages are essential to the innate immunity and pathology of tissue injury and inflammation ${ }^{30}$ through phagocytosis. Macrophages secrete cytokines, such as interleukins, TNF- $\alpha$, and TGF- $\beta$, as well as inflammatory mediators, such as nitric oxide ${ }^{31}$. Macrophages maintain homeostasis and serve an important function in the host defence against pathogens and attacking cells, such as cancer cells ${ }^{32}$. Different plant extracts such as Poulteria cambodiana, Clausena excavate, Nigella seed have shown to increase macrophage proliferation and migration ${ }^{5,33}$. In the present study the crude MEPJ found to increase macrophage proliferation and migration about $40 \%$ and $72 \%$ at the optimum dose of $20 \mu \mathrm{g} / \mathrm{ml}$ concentration.

Inflammation is the response of tissues to injury, characterized in the acute phase through increased blood flow, vascular permeability and the accumulation of fluid, leukocytes and inflammatory mediators, such as cytokines. The immune response in the chronic phase is characterized by the development of specific humoral and cellular immune responses to pathogens at the site of tissue injury ${ }^{34}$. Various immune-related cytokines, such as TNF- $\alpha$, IL-6, and IL-8, are produced by activated macrophages for the modulation and 
orchestration of innate immunity ${ }^{35,36}$. These cytokines can be produced from macrophages in response to bacterial LPS, infection, and inflammatory stimuli. They also play an important role in the immune system by aiding cytotoxic and cytostatic effects on infected or malignant cells ${ }^{37,38}$. The results of this study clearly reveal that the treatments using the plant enhance immune response and stimulate the production of essential mediator cytokines, such as IL-6, and IL-8, which are important in the acute and chronic inflammatory response. IL-6 is important in the stimulation of acute phase protein synthesis in the liver, acts as a growth factor for mature b cells, stimulates their final maturation onto antibody-producing plasma cells, is involved in $\mathrm{T}$ cell activation and differentiation, and affects the induction of IL-2 receptor expression. IL-8 is a potent neutrophil chemotactic factor and has a wide range of actions on the different types of cells, including endothelial cells, fibroblasts, monocytes, lymphocytes, and neutrophils. These functions suggest that IL-8 has important roles in different pathological disorders, such as chronic inflammation and cancer.

TNF- $\alpha$ is one of the earliest factors to be induced or activated in macrophages for eliciting tumor immunity. TNF- $\alpha$ plays as a key mediator of $\mathrm{T}$ lymphocyte and macrophage activation and exerts either beneficial or detrimental effects on mammalian cells by inducing the secretion of NO and PGE2 ${ }^{39,40}$. IL-12 are produced by various immune cells, including macrophages. These cytokines are essential for host survival of infection, and they are required for the repair of injured tissue ${ }^{41,42}$. In the present study, crude MEPJ significantly stimulated the expression of these cytokines. Although further research is needed to identify the active pharmacological constituents of crude MEPJ and to understand the mechanisms of their actions, these findings clearly suggest immune stimulant property of Parkia javanica so far macrophage cells are concerned.

\section{CONCLUSION}

The findings of the present work showed that crude methanol extract of Parkia javanica activates macrophage cells in term of proliferation, migration, pro-inflammatory cytokines release. This strong immuno-modulatory activity of Parkia javanica provides a future basis for the development of this plant as a source of immunoregulating substance.

\section{COFLICT OF INTERESTS}

The authors declare that there is no conflict of interests regarding the publication of this paper.

\section{ACKNOWLEDGEMENT}

We thankfully acknowledge Department of Biotechnology, Govt. of India (DBT Sanction Order No. BT/468/NE/TBP/2013 and Dated-13/3/2014), for financial support. We acknowledge State Biotech hub, Tripura University, for technical support.

\section{REFERENCES}

1. Abood et al. Immunomodulatory effect of an isolated fraction from Tinospora crispa on intracellular expression of INF- $\gamma$, IL-6 and IL-8. BMC Complemntary and Alt Med 2014; 14: 205.

2. Saroj P, Verma M, Jha K. An overview on immunomodulation. J Adv Sci Res 2012; 3(1): 7-12.

3. Mishra K, Ganju L, Sairam M, Banerjee P, Sawhney R. A review of high throughput technology for the screening of natural products. Biomed Pharmacotherapy 2008; 62(2): 94 98.

4. Jashua N, Godfrey SB, Lawrence FS, James G, Josephine NK. Immunomodulatory activity of methanolic leaf extract of Moringa oleifera in Wistar albino rats. J Basic Clin Physiol Pharmacol. 2015; 26(6): 603-611.

5. Madakkannu B., Ravichandran R. Immunomodulatory activity of Indigofera tinctoria leaf extract on in vitro macrophage responses and lymphocyte proliferation. Int J Pharm Pharm Sci 2016; 8(7): 58-63.

6. Jakhar R, Paul S, Chauhan AK, Kang SC. Morin hydrate augments phagocytosis mechanism and inhibits LPS-induced autophagic signaling in murine macrophages. Int Immunopharmacol 2014; 22:356-65.

7. Kudrin A, Ray D. Cunning factor: macrophage migration inhibitory factor as a redox-regulated target. Immunol Cell Biol 2008; 86:232-8

8. Krneta T, Gillgrass A, Ashkar AA. The influence of macrophages and the tumor microenvironment on natural killer cells. Curr Mol Med 2013; 13: 68-79.

9. Schultze JL, Schmidt SV. Molecular features of macrophage activation. Semin Immunol 2015; 27: 416-23.

10. McCabe A, Mac Namara KC. Macrophages: key regulators of steady-state and demand-adapted hematopoiesis. Exp Hematol 2016; 44: 213-22.

11. Murakami A, Ohigashi H. Targeting NOX, INOS and COX-2 in inflammatory cells: chemoprevention using food phytochemicals. Int J Cancer 2007; 121: 2357-63.

12. Balkwill F. Tumour necrosis factor and cancer. Nat Rev Cancer 2009; 9: 361-71.

13. Kalinski P. Regulation of immune responses by prostaglandin E2. J Immunol 2012; 188:21-8.

14. McNelis JC, Olefsky JM. Macrophages, immunity, and metabolic disease. Immunity 2014; 41:36-48.

15. Decano JL, Mattson PC, Aikawa M. Macrophages in vascular inflammation: origins and functions. Curr Atheroscler Rep 2016; 18:34.

16. Sinha J., Medicinal plants of Manipur, Mass and Sinha Manipur Cultural Integration Conference, Imphal, 1996.

17. Majumder K, Dutta BK, Roy D, Inventory and status of medicinal trees of Tripura, Indian Medicinal Plants. Editor P. C. Trivedi. Avishkar publishers, Distributors, Jaipur, 2009.

18. Bhardwaj S, Gakhar SK, Ethnomedicinal plants used by the tribals of Mizoram to cure cuts \& wounds. Indian J. Traditional knowledge. 2005; 4(1): 75- 80.

19. Nikolic M, Vasic S, Durđevic J, Stefanovic O, Comic L, Antibacterial and anti-biofilm activity of ginger (Zingiber officinale (roscoe) ethanolic extract. Kragujevac J. Sci. 2014, 36 (2014); 129-136.

20. Mosmann T. Rapid colorimetric assay for cellular growth and survival: application to proliferation and cytotoxicity assays. J of Immunological Methods 1983; 65(1-2):55-63.

21. Ebeling S., Naumann K., Pollok S., Wardcki T., Merfort I., Brandner J.M. From a traditional medicinal plant to a rational drug: Understanding the clinically proven wound healing efficacy of Birch Bark Extract. Plos one 2014; 9(1):e86147.

22. Krishnamoorthy JR, Sumitira S., Ranjith MS, Gokulshankar S, Ranganathan S, Mohanty BK, Prabhakaran G. An in vitro study of wound healing of a polyherbal formulation as evidence by enhanced cell proliferation and cell migration. EDOJ 2012; 8(1):1.

23. Das N, Mandala A, Naaz S. Melatonin protects against lipidinduced mitochondrial dysfunction in hepatocytes and inhibits stellate cell activation during hepatic fibrosis in 
mice". J Pineal Res. 2017; 62:e12404. https://doi.org/10.1111/jpi.12404.

24. Dinda M, Mazumdar S, Das S, Ganguly D, Dasgupta UB, Dutta A, Jana K and Karmakar P. The water fraction of Calendula officinalis hydroethanol extract stimulates in vitro and in vivo proliferation of dermal fibroblasts in wound healing. Phytotherapy Research 2016; 30: 1696-1707.

25. Davicino R, Mattar A, Casali Y, Porporatto C, Correa SG, Micalizzi B. In vivo immunomodulatory effects of aqueous extracts of Larrea divaricata Cav. Immunopharmacol Immunotoxicol. 2007; 29:351-66.

26. Limem-Ben Amor I, Harizi H, Ghedira K, Chekir-Ghedira L. Leaf extracts from Phlomis crinita Cav. subs. Mauritanica Munbyaffects immune cell functions in vitro, Immunopharmacol Immunotoxicol 2010; 29:1-6.

27. Agarwal SS, Singh VK. Immunomodulators: a review of studies on Indian medicinal plants and synthetic peptides: part I. Medicinal plants. Proc Indian Nat Sci Acad. 1999; 65:179-204.

28. Limem-Ben Amor I, Skandrani I, Boubaker J, Ben Sghaïer $\mathrm{M}$, Neffati A, Bhouri W, et al. Investigation of the biological activity of polar extracts isolated from Phlomis crinita Cav ssp. mauritanica Munby. Drug Chem Toxicol. 2009; 32:3846.

29. Girotti M, Evans JH, Burke D, Leslie CC: Cytosolic phospholipase A2 translocates to forming phagosomes during phagocytosis of zymosan in macrophages. J Biol Chem 2004; 279(18):19113-19121.

30. Robert C, Lu X, Law A, Freeman TC, Hume DA: Macrophages.com: an on-line community resource for innate immunity research. Immunobiology 2011; 216(11):12031211.

31. Stojanovic I, Mirkov I, Kataranovski M, Glamoclija J, StosicGrujicic S: A role for macrophage migration inhibitory factor in protective immunity against Aspergillus fumigatus. Immunobiology 2011; 216(9):1018-1027.

32. Gamal-Eldeen AM, Amer H, Helmy WA: Cancer chemopreventive and anti-inflammatory activities of chemically modified guar gum. Chem Biol Interact 2006; 161(3): 229-240.

33. Elmowalid G, Amar AM, Ahmad AA. Nigella sativa seed extract: Enhancement of sheep macrophage immune functions in vitro. Res Vet Sci 2013; 95:437-43.

34. Feghali CA, Wright TM: Cytokines in acute and chronic inflammation. Front Biosci 1997; 2(1): d12-d26.

35. Schultze JL, Schmidt SV. Molecular features of macrophage activation. Semin Immunol 2015; 27:416-23.

36. Lavelle EC, McGuirk P, Mills KH. Molecules of infectious agents as immunomodulatory drugs. Curr Top Med Chem 2004; 4:499-508.

37. Morris MC, Gilliam EA, Li L. Innate immune programing by endotoxin and its pathological consequences. Front Immunol 2015; 5:680.

38. Sherwin C, Fern R. Acute lipopolysaccharide-mediated injury in neonatal white matter glia: role of TNF-alpha, IL1 beta, and calcium J Immunol 2005; 175:155-61.

39. Balkwill F. Tumour necrosis factor and cancer. Nat Rev Cancer 2009; 9:361-71.

40. Vivier E, Raulet DH, Moretta A, Caligiuri MA, Zitvogel L, Lanier LL. Innate or adaptive immunity? The example of natural killer cells. Science 2011; 331:44-9.

41. McCabe A, MacNamara KC. Macrophages: key regulators of steady-state and demand-adapted hematopoiesis. Exp Hematol 2016; 44:213-22.

42. Morris MC, Gilliam EA, Li L. Innate immune programing by endotoxin and its pathological consequences. Front Immunol 2015; 5:680. 